\title{
Tracer Clearance
}

National Cancer Institute

\section{Source}

National Cancer Institute. Tracer Clearance. NCI Thesaurus. Code C94992.

The process of a radioactive tracer leaving a tissue over time. 